\title{
Pulmonary embolus arising from sloughed off myoma in late puerperium
}

\author{
Geç lohusalıkta myoma bağlı pulmoner embolizm
}

\author{
Ahmet Mete Ergenoğlu, Ahmet Özgür Yeniel, Murat Ulukuş, Niyazi Aşkar \\ Department of Obstetrics and Gynecology, Faculty of Medicine, Ege University, İzmir, Turkey
}

\section{Abstract}

Pulmonary embolus is a rare and serious complication of myoma uteri in the puerperium that resulted in late postpartum hysterectomy A 38-year-old, multiparous woman with a large myoma located on the left lateral wall of the uterus underwent emergency cesarean section due to fetal distres at 28 weeks. During the operation, a $15 \mathrm{~cm}$ sized intramural myoma was left without any intervention. On the $40^{\text {th }}$ day postpartum the patient returned to the clinic with sepsis and pulmonary embolus because of obstruction of lochia drainage by the sloughed off myoma. The patient underwent hysterectomy and medical therapy for pulmonary embolus.

We presented an unusual complication of uterine leiomyoma in the late postpartum period after cesarean section. Whatever the mode of sloughing off ofthe myoma, the results of the obstruction of lochia drainage may be devastating as in our case. To avoid these complications, clinicians must be aware of these symptoms and prompt intervention is essential.

(J Turkish-German Gynecol Assoc 2010; 11: 160-2)

Key words: Myoma uteri, pregnancy, puerperium, pulmonary embolus, sepsis

Received: 22 December, 2009

Accepted: 11 February, 2010

\section{Özet}

Lohusalıkta myoma uteriye bağlı oluşan pulmoner emboli seyrek ve ciddi bir komplikasyondur. Otuzsekiz yaşında, lateral uterus duvannda $15 \mathrm{~cm}$ myomu olan multipar hasta, 28 hafta gebe iken fetal distress nedeniyle acil sezaryene alınd. Operasyonda myoma dokunulmadı. Hasta lohusalığının 40. gününde myomun drenajı bozması nedeniyle Ioşiye bağlı pulmoner emboli ve sepsis yakınması ile müracaat etti. Hastaya acil histerektomi yapıldı, pulmoner emboli için de medikal tedavi planlandı. Burada geç postpartum görülen bir pulmoner emboli vakası bildirilmiştir. Burada asıl sorun myomun Ioşi akışını bloke etmesi idi. Bu nedenle klinisyen uyanık olmalı ve gerekli girişimi yapmalıdır.

(J Turkish-German Gynecol Assoc 2010; 11: 160-2)

Anahtar kelimeler: Myoma uteri, gebelik, lohusalık, pulmoner emboli, sepsis

Geliş Tarihi: 22 Aralık 2009

K abul Tarihi: 11 Şubat 2010
Uterine leiomyomas (fibroids, myomas) are the most common benign tumors of the uterus with an incidence of $20-25 \%$ in reproductive years $(1,2)$. In pregnancy, leiomyomas occur approximately $1 \%$ of the time, with a range $0.3 \%$ to $2.6 \%$ (3). The reported incidence of myomas complicating pregnancy is less than $1 \%$ and these complications are spontaneous abortions, fetal growth restriction, preterm labor, dystocia, fetal malpresentation, abruptio placenta, retained placenta and postpartum hemorrhage (4-7). Many of these complications are closely related with the size and the location of the myoma. In addition, some authors suggest that leiomyomas cause an increased incidence of cesarean delivery and cesarean hysterectomies (8).

The purpose of this case report is to remind clinicians that leiomyoma in pregnancy may cause rare but serious complications like sepsis and pulmonary embolism in the late postpartum period and this may result in loss of fertility.

\section{Case}

A 38-year-old woman gravida 7, para 4 was admitted to the clinic of the obtetrics and gynaecology of Ege University with high blood pressure. Although she did not know her exact last menstural period, ultrasonographic examination revealed a 28 week fetus and a myoma which was $110 * 190$ $\mathrm{mm}$ in dimension. It was localized in the left lateral wall of the uterus. Blood pressure was 150/90 mm Hg. Routine biochemical, hematological and urine parameters were studied. These tests were all remarkable with excess protein in urine. In view of the foreging, the patient was diagnosed as preeclamsia. Basal cardiotocography revealed repetitious late deceletations that shows fetal distress so a cesarean section was performed. We delivered a $1220 \mathrm{gr}$ male fetus with thick meconium in the amniotic fluid. He was transferred to the neonatal intensive care unit. During the operation a $15 \mathrm{~cm}$ 
intramural myoma was observed on the left lateral wall of the uterus. The myoma was left in place and bilateral tubal ligation of Pomeroy was executed with the patient's consent. The patient was discharged on the $7^{\text {th }}$ postoperative day

On the $40^{\text {th }}$ postpartum day the patient was admitted to our clinic with fever, abdominal pain, malodorous vaginal discharge and dyspnea. Physical examination revealed that the patient has abdominal and uterine tenderness and a purulant malodorous discharge from the cervix was observed on speculum examination. Uterus was in subinvolution and the fundus was palpated $3 \mathrm{~cm}$ over the umblicus. Her vital signs, blood pressure, fever, heart rate, respiratory rate were $120 / 80 \mathrm{~mm} \mathrm{Hg}$, $38^{\circ} \mathrm{C}, 130$ pulse/min. and 36/min respectively. Emergency arterial blood gas analyses revealed respiratory alkalosis. In complete blood count study hemoglobin, wbc and platelets were $9.9 \mathrm{~g} / \mathrm{dl}, 16000 / \mathrm{mm}^{3}$ and $110000 / \mathrm{mm}^{3}$ respectively. D-dimer was over $4355 \mathrm{micg} / \mathrm{l}$ and C-reactive protein was $35.49 \mathrm{mg} / \mathrm{dl}$. In this presentation we suspected sepsis and pulmonary embolism so thoracic angio tomographic(CT), abdominal CT and echographic investigations were performed.

In the cardiac echo examination a $22 * 14 \mathrm{~mm}$ sized thrombus was diagnosed in the bifurcation of the pulmonary artery (Figure 1) and on thoracic angio CT, multiple thrombi were diagnosed bilaterally in the pulmonary arteries especially on the right side (Figure 2). Also on the right lower segment an acute infarct was observed. Abdominal CT reported $9 \mathrm{~cm}$ sized mass and pyometria in the cavity of the uterus.

With the diagnoses of postpartum endometritis, sepsis and secondary pulmonary embolism, the patient was given intravenous broad spectrum antibiotherapy and low molecular weighted heparin. After stabilisation, the patient underwent hysterectomy. Abdominal inspection during surgery revealed that the uterus was in subinvolution without free fluid in the abdomen. Hysterectomy was performed without complication. On macroscopic inspection, the uterus was incised longitudinally from fundus to cervix. We observed that the uterine cavity was full of pyometria and a $12 \mathrm{~cm}$ sized myoma was protruding from the submucous layer to the internal cervical os and was obstructing the drainage of lochia (Figure 3).

During the postoperative period, fever was decreased and uneventful. Microscopic examination of operation material was reported as necrotic myoma, acute endometritis and pyometria.The patient was discharged with anticoagulant therapy on the $12^{\text {th }}$ postoperative day.

\section{D iscussion}

Pregnancy and postpartum complications seem to be more common with larger and submucosal myomas that located below the placental attacthment (5). There is a variable progression of myoma in pregnancy reported by several studies $(5,9)$. Enlargement of the myoma in pregnancy was seen only $32 \%$ of the pregnants and the greatest enlargement was observed before 10th week of gestation. Conversly reduction of the size of myoma occurs in puerperium period. In our case we did not see significant reduction in size of the myoma (operation day size $15 \mathrm{~cm}$, postpartum $42^{\text {th }}$ day size $12 \mathrm{~cm}$ ) but change of location

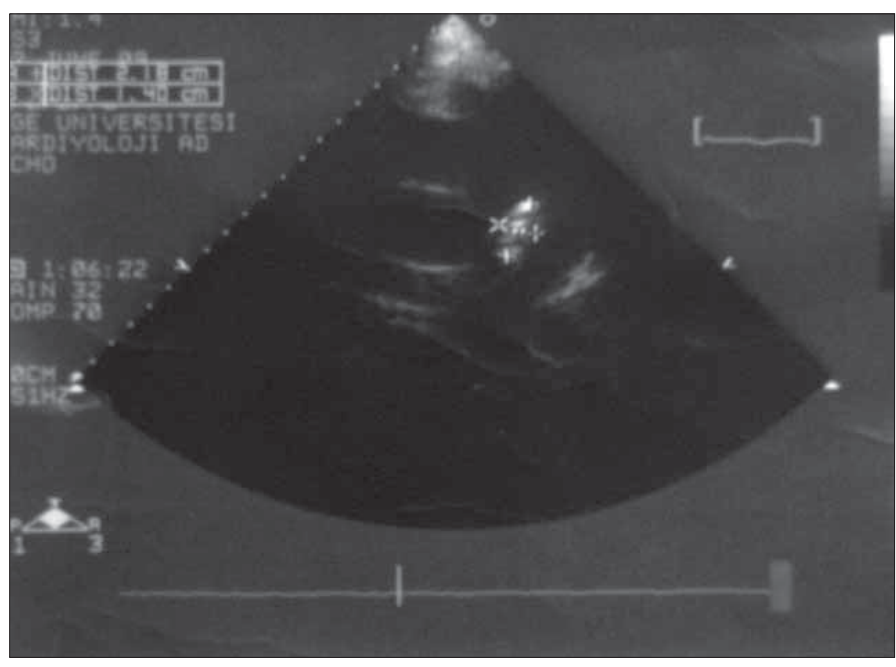

Figure 1. Thrombus in echocardiography was seen as echogenic focus

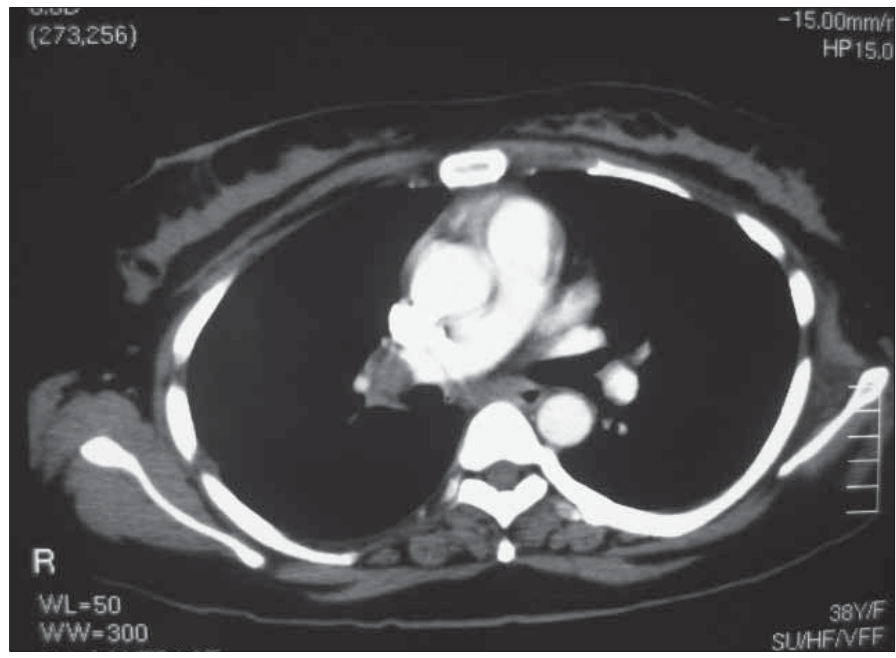

Figure 2. Multiple thrombi was diagnosed in the bifucation of pulmonary artery on thoracic angio CT

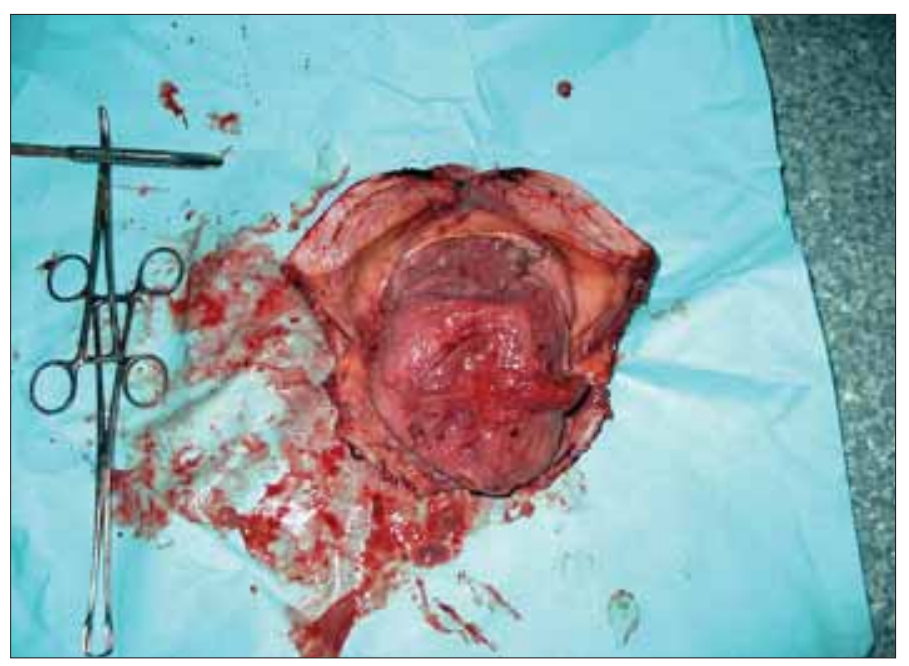

Figure 3. U terine cavity and myoma protruding from submucous layer was seen after hysterectomy 
from intramural to submucosal in uterus. Changing location of myomas in puerperial period was defined by many authors in literature (10-12). Route of myoma in portpartum period either subserosal or submucosal may be seen. Some authors suggest that this changing location especially to subserosal route makes operations of myomectomy easier than achieved in delivery period (11). Although subserosal transformation is good candidate for minimal invasive surgery, submucosal transformation accompany with some complications especially by obtructing the drainage of lochia such as postpartum haemorrhage, infectious complications, disseminated intravascular coagulation and pulmonary embolus.

Murakami et al. (10) discussed about mechanism of sloughing off the myomas during the puerperium. In summary they suggest that there may be three way of expulsion of the myomas to the endometrial cavity. First one is reduction of the blood supply by the delivery during the puerperium. This causes relative ischemia and than degeneration. Normal uterine tissue may provoke expulsion of the degenerative myoma. Similar actions and pathways are seen after uterine artery embolization (13-15), bipolar coagulation of uterine artery (16), and gonadotropin releasing hormone $(\mathrm{GnRH})$ agonist therapy (17-19). Second way is rapid involusion of uterus and on the other side myomas may be the out of step with this involusion. As a result, prompt involusion may expulses myomas to the either submucosal or subserosal localization. Same mechanism may be seen in $\mathrm{GnRH}$ agonist therapy and uterine artery embolization which cause rapid atrophy of uterus. Third way is the endometrial changes over the myomas makes it easier to be sloughed off. However this may be seen in puerperial 3. or 4. weeks, it may be seen in other hormonal therapies like GnRH agonist therapy (18). In our case we also observed same mechanism but different results. In postpartum period intramural myoma transformed to submucosal myoma and this myoma sloughed off to the uterine cavity. This myoma obstructed the passage; lochia and necrotic myoma became infected. This infection and necrosis progresses to sepsis and maybe pulmonary embolism.

Akrivis et al. (12) described a case of primary postpartum haemorrhage due to a large submucosal leiomyoma. It was the same way of sloughing off the myoma but different complication. Complication was postpartum haemorrhage due to atonia which was resulted deep anemia and emergency postpartum hysterectomy. Authors suggest that obstruction of passage by myoma was the cause of atony bleeding.

The maternal hypercoagulable state is a physiological preparation for delivery however, this hypercoagulability is associated with an increased risk of venous thromboembolism. The elements of Virchow's triad (venous stasis, vascular damage, and hypercoagulability) are all present during pregnancy and the postpartum period. Additionally obesitiy, immobilisation, thrombophilia, smoking, advanced age, intrapartum haemorrhage, parity, infection and cesarean section are the risk factors for pulmonary embolism either intrapartum or postpartum period (20). In our case although most of the risk factor were already present, infection caused by incomplete drainage and mass effect of uterus with giant myoma might be additional reason for pulmonary embolus.
In conclusion we presented an unusual complication of uterine leiomyoma in late postpartum period after cesarean section. Whatever the way of sloughing off the myoma is, results of the obstruction of lochia drainage may be devastating as we see in our case. To avoid these complications, clinicians must be aware of these symptoms and promptly intervention is needed.

\section{Conflict of interest}

No conflict of interest is declared by authors.

\section{References}

1. Stewart EA. Uterine fibroids. Lancet 2001; 357: 293-8.

2. Buttram VC, Reiter RC. Uterine leiomyomata: etiology, symptomatology, and management.Fertility and Sterility 1981; 36: $433-45$.

3. Muram D, Gillieson M, Walters J H. Myomas of the uterus in pregnancy: ultrasonographic follow-up. Am J Obstet Gynecol 1980; 138: 16-9.

4. Simon FA. Leiomyomas in pregnancy. Am Fam Phys 1988; 37: 163-6.

5. Exacoustos C, Rosati P. Ultrasound diagnosis of myomas and complications inpregnancy: Obstet Gynecol 1993; 82: 97-101.

6. Chuang J, Tsai HW, Hwang JL. Fetal compression syndrome caused by myoma in pregnancy: a case report. Acta Obstet Gynecol Scand 2001; 80: 472-3.

7. Varras M, Antoniou S, Samara Ch, Frakala S, Angelidou-Manika Z, Paissios P. Intraperitoneal haemorrhage secondary to perforation of uterine fibroid after cystic degeneration. Unusual CT findings resembling malignant pelvic tumor: case report. Eur J Gynaecol Oncol 2002; 23: 565-8.

8. Rice JP, Kay HH, Mahony BS. The clinical significance of uterine leiomyomas in pregnancy.Am J Obstet Gynecol 1989; 160: 1212-6.

9. Rosati P, Exacoustòs C, Mancuso S. Longitudinal evaluation of uterine myoma growth during pregnancy. A sonographic study.J Ultrasound Med 1992; 11: 511-5.

10. Murakami T, Niikura H, Shima Y, Terada Y, Okamura K. Sloughing off of a cervical myoma after cesarean section: a case report.J Reprod Med 2007; 52: 962-4.

11. Haskins RD J r, Haskins CJ, Gilmore R, Borel MA, Mancuso P. Intramural leiomyoma during pregnancy becoming pedunculated postpartally. A case report. J Reprod Med 2001; 46: 253-5.

12. Akrivis Ch, Varras M, Bellou A, Kitsiou E, Stefanaki S, Antoniou N. Primary postpartum haemorrhage due to a large submucosal nonpedunculated uterine leiomyoma: a case report and review of the literature.Clin Exp Obstet Gynecol 2003; 30: 156-8.

13. Abbara S, Spies J B, Scialli AR, J ha RC, Lage J M, Nikolic B. Transcervical expulsion of a fibroid as a result of uterine artery embolization for leiomyomata.J Vasc Interv Radiol 1999; 10: 409-11.

14. Berkowitz RP, Hutchins FL J r, Worthington-Kirsch RL. Vaginal expulsion of submucosal fibroids after uterine artery embolization. A report of three cases.J Reprod Med 1999; 44: 373-6.

15. Al-Fozan $\mathrm{H}$, Tulandi $\mathrm{T}$. Factors affecting early surgical intervention after uterine artery embolization. Obstet Gynecol Surv 2002; 57: 810-5.

16. Liu WM, Yen YK, Wu YC, Yuan CC, Ng HT. Vaginal expulsion of submucous myomas after laparoscopic-assisted uterine depletion of the myomas. J Am Assoc Gynecol Laparosc 2001; 8: 267-71.

17. West CP, Lumsden MA, Lawson S, Williamson J, Baird DT. Shrinkage of uterine fibroids during therapy with goserelin (Zoladex): a luteinizing hormone-releasing hormone agonist administered as a monthly subcutaneous depot.Fertil Steril 1987; 48: 45-51.

18. Perl V, Marquez J, Schally AV, Comaru-Schally AM, Leal G, Zacharias $\mathrm{S}$, et al. Treatment of leiomyomata uteri with D-Trp6-luteinizing hormone-releasing hormone.Fertil Steril 1987; 48: 383-9.

19. Ellenbogen A, Shulman A, Libal $Y$, Jaschevatzky O, Anderman $S$, Grunstein S. Complication of triptorelin treatment for uterine myomas. Lancet 1989; 2: 167-8.

20. Bourjeily G, Paidas M, Khalil H, Rosene-Montella K, Rodger M. Pulmonary embolism in pregnancy. Lancet 2010; 375: 500-12. 